\title{
ADOPTION OF IMPROVED PRODUCTION PRACTICES IN LOW LAND RICE THROUGH COMMUNITY TRAINING
}

\author{
M.H. Rashid ${ }^{1 *}$, M.K.I. Rony ${ }^{2}$, D. Mahalder $^{2}$ and P.C. Goswami ${ }^{2}$ \\ ${ }^{1}$ Crops Division, Bangladesh Agricultural Research Council, Farmgate \\ New Airport Road, Dhaka-1215, Bangladesh \\ ${ }^{2}$ International Rice Research Institute, House-103, Road 1, Block F, Banani \\ Dhaka-1213, Bangladesh
}

\begin{abstract}
Rice (Oryza sativa L.) production technology adoption requires effective farmers' training for narrowing knowledge gap. This paper assesses the result of community training on the extent of adoption of improved rice production practices in low land rice of south western Bangladesh. A total of 531 farmers were trained through community training approach and 177 farmers were randomly selected for data collection. The extent of adoption of improved rice production practices and reasons for nonadopting technologies were solicited by personal interview with the help of a semi-structured questionnaire. Collected data were analysed using descriptive and inferential techniques. The community training was suited to adopt rice production technologies. The adoption of different rice production technologies was greater by the adopters of Satkhira district compared to Khulna that resulted in significant rice yield difference. The constraints against the adoption of the selected rice production technologies show that a portion of adopters was not convinced to adopt row transplanting, skipped row planting and birds perch for controlling insects, use of appropriate $\mathrm{K}$ and $\mathrm{S}$ fertilizers due to requirement of higher labour and fertilizer and risk of reduction of rice yield. The integration of other extension methods such as method and result demonstration might enhance the rate of adoption of those rice production technologies.
\end{abstract}

Keywords: Technology Adoption, Community Training, Productivity; Rice Technology

\section{INTRODUCTION}

Rice (Oryza sativa L.) is staple food in Bangladesh. A large section of the population of the country depends on rice production and processing. Rice is grown in $72 \%$ of

\footnotetext{
*Corresponding author: hrashid67@yahoo.com
} 
the total cropped area of the country which accounts for more than $90 \%$ of total grain production (BBS, 2018). The rapid population growth and urbanisation gradually decreased the cultivated land demanding increased output to keep pace with the population increase. To assure food security, rice production would have to be increased by $50 \%$ by 2025 as a rice consuming country (Zeng et al., 2004). Rice is grown in Bangladesh in winter, pre-monsoon and monsoon seasons covering 4.48, 1.14 and $5.59 \mathrm{~m}$ ha, respectively. The monsoon season rice is known as Aman rice, mainly grown under rainfed condition characterized by low productivity and income with an average yield of $3.71 \mathrm{t} \mathrm{ha}^{-1}$ (BBS, 2018). The low level of production resources, low adoption of improved agronomic practices and inadequate extension delivery system constraint its productivity which affect many farming families, particularly those who operate farming in unfavorable environments.

The success of any technology depends on its dissemination among the potential users, which ultimately is measured by the level of adoption of that technology (Reddy and Reddy, 2002). Mosher (1987) defined that adoption of an innovation is the process by which a particular farmer is exposed to, considers, and finally rejects or practices a particular innovation. Adoption decisions are mainly affected by extension related variables such as training, membership in a farmers' group, and offfarm employment (Suvedi et al., 2017). Farmers sometimes discover problems in putting a recommendation into practice, the extent of adoption, adjustment or rejection depends on farmers' behavior (Valera and Plopino, 1987). Effective farmers' training is one of the options to adopt rice production technologies (Sarma et al., 2011). Tsado et al. (2014) opined that training for rice farmers needs to be given topmost priority to improve their skills on the adoption of improved rice production packages to increase their productivity and consequently their income. However, various studies indicated that there was a wide gap between available technology and its adoption in rice cultivation under different farming situations.

Learning of community environments aided with rich training materials such as graphics, video and other media and educational materials helped learners to discover things by themselves (Deegan et al., 2016). Learners are becoming more diverse in their needs and learning styles. The instructional method prepared in terms of learners learning style act as the most effective one (Bovy, 1981). Educational literature suggests that individuals demonstrate a preference for particular information-processing styles to assimilate new information (Eastman, 2010). The integrated training course blending different methods affords flexibility that serves the learning styles of diverse learners (Albion and Redmond, 2006). Therefore, the study was conducted to: i) determine the levels of adoption of rice production technologies by the trained farmers in the study area, ii) assess the influence of rice production technology adoption on the yield of rice and iii) identify major constraints in adopting rice production technologies by the adopted farmers. 


\section{MATERIALS AND METHODS}

\section{The Study area}

The study conducted in the south-western coastal region of Bangladesh belongs to the Ganges Tidal Flood Plain, Agro-Ecological Zone (AEZ) 13. This region is almost flat and is about $1 \mathrm{~m}$ above the sea level. The average annual rainfall of the area is $1710 \mathrm{~mm}$ where rainfall occurs mainly from June to September. Monthly mean minimum temperature is $12.5^{\circ} \mathrm{C}$ in January and the maximum is $35.5^{\circ} \mathrm{C}$ in May. The soils of the study area are clay loam to clay in texture.

\section{Community training on rice production packages}

A day long farmer's training on rice production was conducted at each of the 36 villages under 21 Unions of 7 Upazilas (sub-districts) of Khulna and Satkhira districts in south-western Bangladesh. Twenty-five to 30 farmers of both male and female were selected in a community for a batch of training. The small and medium farmers were selected through discussion with the community following the principle that at least $10 \%$ trainee would be female. The training was conducted before the crop growing activities i.e. during June and July 2014 which permitted for discretionary learning and successful application and bringing this into practice. The training sessions were conducted at suitable places of the community like school, Union Parishad (council or assembly) Complex, houses of some lead farmers and under the shade of big trees. The mode of training was informal. Participants were encouraged to share their experiences in rice production, processing, and storage of seeds. The facilitators tried to find out the gaps between their practices and the recommended packages of rice production. The facilitators facilitated the sessions using flip charts, real learning aid or samples like disease and insect infested rice plant, bad and good quality seeds. Practical skills such as seedling raising in a raised bed, seedling uprooting and transplanting with an optimum number of seedlings at an optimum spacing, seed production, processing and storing were demonstrated utilizing multi-media material with audio dialogue through discussing the process step-by-step guide. In order to ensure the farmer not overawed by receiving too much information at once, the video materials were delivered in a small segment.

\section{Data collection}

A total of 531 farmers were trained of which 177 farmers were selected randomly for data collection. The extent of adoption of rice production practices, grain yield obtained in the technology adopted fields was the dependent variable. Age, education, farming experiences of the sampled farmers was recorded. Some focus group-discussions were conducted in six randomly selected trained communities both in Khulna and Satkhira districts for listing the reasons against not adopting the improved practices and were included in the questionnaire for data collection from the selected respondents. Data were solicited by personal interview method with the help of a semi-structured questionnaire just after harvesting of rice during November 
to December 2014. The grain yield was measured from the adopted farmer's fields, at the central part of the plot of $20 \mathrm{~m}^{2}$ sample area and was adjusted to $14 \%$ moisture.

\section{Data analysis}

Farmers were trained on ten different rice production practices (four on fertilizer recommendations, six on other crop production practices) to adopt to their rice fields. Collected data were analyzed using both descriptive and inferential techniques. The extent of adoption of rice production practices was measured against a two-point rating scale of 1 for "adoption" and 0 for "non-adoption". In the case of adoption of the amount of fertilizer use and time of application, 5 to $10 \%$ variation was considered as adoption. The extent of adoption of agreed rice production practices was compared at the district level adopters. Data on grain yield of rice was analyzed with CROPSTAT 7.2 version. The least significant difference (LSD) was used at $(\mathrm{P}<0.05)$ to test the differences among the treatment means.

\section{RESULTS}

\section{Characteristics of rice farmers in the study area}

Among the trained farm member, the majority were in the age of 40-59 years (51.4\%) followed by the group of 25-39 years old (47.5\%). Farmers aged 60 and above were only $1.1 \%$ (Table 1 ).

Table 1. Age and level of education of the trained farmers.

\begin{tabular}{l|c|c}
\hline \multirow{2}{*}{ Age and level of education } & \multicolumn{2}{|c}{ Trained farmers } \\
\cline { 2 - 3 } & Number of farmer & Percentage \\
\hline Farmer's age (years) & 84 & \\
$25-39$ & 91 & 47.5 \\
$40-59$ & 2 & 51.4 \\
$\geq 60$ & 177 & 1.1 \\
Total & & 100.0 \\
Education level & 10 & \\
Illiterate & 82 & 5.6 \\
Primary & 76 & 46.3 \\
Secondary & 8 & 42.9 \\
Higher secondary & 1 & 4.5 \\
Graduate & 177 & 0.7 \\
Total & & 100.0 \\
\hline
\end{tabular}


Farmers were mostly from the education level of primary (46.3\%) and secondary $(42.9 \%)$. Only 5.6 and $4.5 \%$ adopters were from the illiterate group and higher secondary level of education, respectively. Whereas, the graduate farmers were less than $1 \%$ showed in Table 1. Maximum of the adopters had the farming experiences of 6 to 20 years $(63.9 \%)$. Only $11.3 \%$ farmers were from 5 years and $9.6 \%$ were from 21-25 years of farming experiences. The rest of the farmers were from 26 years to 41 years of age (Table 2).

Table 2. Farming experiences of the trained farmers.

\begin{tabular}{l|c|c}
\hline \multirow{2}{*}{ Farming experience (years) } & \multicolumn{2}{|c}{ Trained farmers } \\
\cline { 2 - 3 } & Number of farmer & Percentage \\
\hline$\leq 5$ & 20 & 11.3 \\
$6-10$ & 38 & 21.5 \\
$11-15$ & 37 & 20.9 \\
$16-20$ & 38 & 21.5 \\
$21-25$ & 17 & 9.6 \\
$26-30$ & 14 & 7.9 \\
$31-35$ & 8 & 4.5 \\
$36-40$ & 4 & 2.3 \\
$\geq 41$ & 1 & 0.5 \\
Total & 177 & 100.0 \\
\hline
\end{tabular}

\section{Rice production technology adoption}

The adoption of different rice production technologies was greater by the adopters of Satkhira district as compared to Khulna district except skipped raw transplanting (Table 3). Skipped raw transplanting was slightly higher in Khulna district. However, the magnitude of difference varied among crop management practices. In general, the adoption of skipped row transplanting for seed production was lower.

\section{Rice yield of technology adopters and constraints to adoption of rice production technology}

Grain yield of trained farmers of Satkhira $\left(5.12 \mathrm{t} \mathrm{ha}^{-1}\right)$ was significantly greater than those of Khulna district $\left(4.84 \mathrm{t} \mathrm{ha}^{-1}\right)$. The constraints against the adoption of the selected rice production technologies showed that a portion of adopters was not convinced to adopt row transplanting, skipped row planting and birds perch for controlling insects, especially rice stem borer and rice leaf roller, use of appropriate $\mathrm{K}$ and $\mathrm{S}$ fertilizers (Tables 4 and 5). The major constraints to adoption of the raisedbed method of seedling raising that the higher cost of land preparation for raising 
land followed by lack of sufficient land. They perceived that the raised bed system needed much land. Unavailability of the two-wheel tractor (power tiller) for ploughing the main field mainly constrained the adoption of seedling of optimum age. Other reasons for older seedling use were the late onset of rainfall, seedling damage due to stagnant water and unavailability of labour during transplanting. More than $27 \%$ trainees reported that they did not adopt row transplanting as it required more labourers. The trained farmers used higher number of seedlings per unit area instead of an optimum number of seedlings with a perception of lower tillering with fewer seedlings and thus grain yield might be reduced. The farmers who did not adopt skipped row for rice seed production mentioned that its adoption was not possible as the labourers were not habituated, and yield might be decreased. Birds perch, a technology for insect controlling did not convince a portion of trained farmers mainly due to its efficacy depends on the use by the whole community. Moreover, reluctant to new technology adoption also hampered the adoption of those technologies.

Table 3. Rice production technology adoption by the trained farmers of Khulna and Satkhira.

\begin{tabular}{l|c|c}
\hline \multirow{2}{*}{ Technologies adopted } & \multicolumn{2}{|c}{ Rate of adoption $(\%)$} \\
\cline { 2 - 3 } & Khulna & Satkhira \\
\hline Raised bed & 76.4 & 87.4 \\
Younger seedling & 77.6 & 93.5 \\
Skipped row transplanting & 59.1 & 55.6 \\
Seedling per hill & 55.9 & 91.0 \\
Bird perch for insect & 64.2 & 82.3 \\
management & & \\
Fertilizer dose \& method of application & & 88.8 \\
Urea & 82.7 & 92.4 \\
TSP & 84.3 & 92.8 \\
MOP & 79.1 & 91.3 \\
Gypsum & 54.3 & \\
\hline
\end{tabular}


Table 4. Constraints to adoption rice production technologies other than fertilizer by the trained farmers.

\begin{tabular}{|c|c|c|c|c|c|c|}
\hline \multirow{2}{*}{$\begin{array}{l}\text { Constraints to technology } \\
\text { adoption }\end{array}$} & \multicolumn{6}{|c|}{ Technology adopted by the trained farmers (\%) } \\
\hline & $\begin{array}{l}\text { Raised } \\
\text { seedbed }\end{array}$ & $\begin{array}{l}\text { Optimum } \\
\text { seedling } \\
\text { age }\end{array}$ & $\begin{array}{c}\text { Row } \\
\text { transpl } \\
\text { anting }\end{array}$ & $\begin{array}{l}\text { Optimum } \\
\text { seedling } \\
\text { hill }^{-1}\end{array}$ & $\begin{array}{c}\text { Skipped } \\
\text { row } \\
\text { planting }\end{array}$ & $\begin{array}{l}\text { Birds } \\
\text { perch }\end{array}$ \\
\hline High land preparation cost & 13.0 & $-^{\dagger}$ & - & - & - & - \\
\hline $\begin{array}{l}\text { Lack of sufficient land for } \\
\text { seedbed }\end{array}$ & 6.2 & - & - & - & - & - \\
\hline $\begin{array}{l}\text { Not interested to change } \\
\text { traditional practice }\end{array}$ & 3.4 & - & - & - & - & - \\
\hline Not convinced & 4.0 & 2.8 & 22.6 & 5.7 & 22.0 & 20.9 \\
\hline $\begin{array}{l}\text { Unavailability of power } \\
\text { tiller for ploughing }\end{array}$ & - & 13.6 & - & - & - & - \\
\hline Late onset of rainfall & - & 2.3 & - & - & - & - \\
\hline $\begin{array}{l}\text { Seedling damage due to } \\
\text { stagnant water }\end{array}$ & - & 4.5 & - & - & - & - \\
\hline Unavailability of labour & - & 2.8 & - & - & - & - \\
\hline $\begin{array}{l}\text { Requirement of more } \\
\text { labour }\end{array}$ & - & - & 27.7 & 1.7 & 6.8 & - \\
\hline $\begin{array}{l}\text { Difficult in higher water } \\
\text { depth }\end{array}$ & - & - & 4.0 & - & - & - \\
\hline Unwillingness of labour & - & - & 4.0 & 5.1 & 22.0 & - \\
\hline Poor tillering (growth) & - & - & - & 14.1 & - & - \\
\hline Yield reduction & - & - & - & 17.5 & 38.4 & - \\
\hline Reluctant to adopt & - & - & - & - & - & 15.3 \\
\hline Laggardness of farmer & - & - & - & - & - & 9.0 \\
\hline
\end{tabular}

$\dagger$ Not applicable for the specific constraints to technology adoption

The farmers who were accustomed to using the higher dose of fertilizer did not apply recommended fertilizers as they perceived that the lower dose might decrease the rice yield. On the other hand, the lower dose user did not apply the recommended fertilizer because of lack of capital. Unavailability of quality fertilizer was also reported as a constraint by some of the respondents (Table 5). 
Table 5. Constraints to adoption of recommended fertilizer dose and method of application.

\begin{tabular}{l|c|c|c|c}
\hline \multirow{2}{*}{$\begin{array}{l}\text { Constraints to } \\
\text { technology adoption }\end{array}$} & \multicolumn{4}{|c}{ Technology Adoption by the trained farmers (\%) } \\
\cline { 2 - 5 } & $\begin{array}{c}\text { Nitrogen } \\
\text { fertilizer }\end{array}$ & $\begin{array}{c}\text { Phosphate } \\
\text { fertilizer }\end{array}$ & $\begin{array}{c}\text { Potassium } \\
\text { fertilizer }\end{array}$ & $\begin{array}{c}\text { Sulphur } \\
\text { fertilizer }\end{array}$ \\
\hline $\begin{array}{l}\text { Yield reduction (for } \\
\text { higher dose user) }\end{array}$ & 10.2 & 9.0 & 12.4 & 17.0 \\
$\begin{array}{l}\text { Lack of capital (for } \\
\text { lower dose user) }\end{array}$ & 6.2 & 6.2 & 5.7 & 13.0 \\
$\begin{array}{l}\text { Not convinced } \\
\begin{array}{l}\text { Unavailability of quality } \\
\text { fertilizer }\end{array}\end{array}$ & 4.5 & 6.2 & 10.7 & 13.6 \\
\hline
\end{tabular}

\section{DISCUSSION}

The findings in this study highlight the effectiveness of the use of the community training for rice technology adoption. The study revealed the community training approach as the potential to adopt technologies by trained farmers. The approach could be promoted by extension providers. Conducting training in the community environment with integrated training method, the retention of the message was increased due to reinforcement that resulted in a higher rate of adoption of rice production technologies. Shanthy and Thiagarajan (2011) also revealed that by supplementing the traditional teaching environment with multimedia, the retention of the message was increased.

\section{Training environment and trainees}

Conducting training in the farmers' community environment, selecting trainees through existing farmers' group of a community and creating an opportunity to interact and exercise the practical skill by themselves within groups proved an effective way to mobilize farmers. The success of group activities observed in the present study reinforces earlier findings by Mungala and Chavangi (1996), Davis et al. (2004) and Kiptot et al. (2006) that groups are effective entry points to an extension in communities.

In the present study, the sampled farmers were mostly of middle aged. Age determines to some extent how productively an individual is carrying out agricultural activities. According to Kartasapoetra (1996), it is difficult to change the ways of thinking, working, and life by older farmers.

\section{Technologies and training}

The extent of adoption of technology is influenced by the attributes of technology, characters of adopters and extension providers and the socioeconomic, biological, and physical environment in which the technology take place (Cruz, 1987). The study 
confirms that the community training combining with multiple methods are best suited to adopt rice production technologies especially easy to adopt, similar or less cost involvement and perceived higher yield and income as compared to the technologies which have higher cost involvement such as cost for higher input use or requirement of higher labour and with risk for reduction of rice yield. This is supported by the findings of Lukuyu et al. (2012) and Hossain et al. (2001). A portion of participants was not convinced to adopt some technologies like row transplanting, skipped row planting for seed production and birds perch for controlling insects, especially rice stem borer and rice leaf roller, use of appropriate $\mathrm{K}$ and $\mathrm{S}$ fertilizers. The farmers of the study area were reluctant to use their own seeds of high yielding rice varieties which might discourage to adopt this technology. Ngoc Chi and Yamada (2002) reported that the weak belief on ensuring a high yield of new technology limited the adoption of technology. Sewell et al. (2017) mentioned that barriers to learning and adoption of new technologies included issues of trialability, complexity, compatibility, and risk.

Community training might not be considered alone for adopting all sorts of crop production technologies. The crop production practices required higher farmers' confidence to adopt, the risk involved and costly have to be integrated with other extension methods such as result demonstration, field days and exposure visits and backstopping from extension personnel. McDonald et al. (2016) reported that the decision of technology adoption primarily motivated by financial considerations and were closely related to the perception of usefulness and ease-of-use of a technology.

\section{Sustainability of the community training}

Farmers' training in a distant place decreases the interest of the trainees which is further constrained by the transportation problem (Lukuyu et al., 2012). Conducting training at the real farming environment creates an opportunity to solve this problem.

As female farmers have lots of on-farm and off-farm activities, they feel comfortable in their community and can join other activities just after finishing their training at the community level. The remarkable acceptance and adoption of improved rice production technologies by the farmers improve the productivity of rice and thus a significant increase in annual income, food consumption, expenditure, housing, environment and family status of the framers (Salehin et al., 2009).

\section{CONCLUSION}

The results indicate that the higher rate of technology adopters obtained higher grain yield. Therefore, informal need-based rice production training at the community level could be scaled out for successful technology adoption.

\section{ACKNOWLEDGEMENT}

The authors acknowledge the assistance provided by USAID through the CSISA-BD project that has made this research possible. 


\section{REFERENCES}

Albion, P., and Redmond, P. (2006). Returning the favour: using insights from online learning to enhance on-campus courses. Proceedings of Society for Information Technology \& Teacher Education International Conference, p. 2458-2464.

BBS. (2018). Yearbook of Agricultural Statistics 2017. Bureau of Statistics, Statistics and Informatics Division, Ministry of Planning, Government of the People's Republic of Bangladesh, Dhaka. p. 34-77.

Bovy, R.C. (1981). Successful instructional methods: a cognitive information processing approach. ECTJ 29 (4): 203-217.

Cruz, F.A. (1987). Adoption and diffusion of agricultural extensions. p. 97-127. In: J. B. Valera, V. A. Martinez and Plopino, R. F (eds.), An Introduction to Extension Delivery Systems, Island Publishing House, Manila.

Davis, K., Franzel, S., Hildebrand, P. and Place, N. (2004). Extending technologies among small-scale farmers in Meru: ingredients for success in farmer groups. Journal of Agricultural Extension and Education, 10(2):53-62.

Deegan, D., Wims, P., and Pettit, T. (2016). Practical skills training in agricultural educationa comparison between traditional and blended approaches. The Journal of Agricultural Education and Extension, 22(2):145-161.

Eastman, V. (2010). Small group instruction: reading instruction utilizing learning style preferences and the reading achievement of first grade students. PhD Dissertation; Ball State University.

Hossain, M., Janaiah, A., Husain, M., and Naher, F. (2001). Rice seed delivery system in Bangladesh: institutional and policy issues. Bangladesh Development Studies, 27(4): 1-40.

Kartasapoetra, A.G. (1996). Agricultural Extension Technology. Jakarta: PT. Bumi Aksara.

Kiptot, E., Franzel, S., Hebinck, P., and Richards, P. (2006). Sharing seed and knowledge: farmer to farmer dissemination of agroforestry technologies in Western Kenya. Agroforestry Systems, 68:167-179.

Lukuyu, B., Place, F., Franzel, S. and Kiptot, E. (2012). Disseminating improved practices: are volunteer farmer trainers effective?" The Journal of Agricultural Education and Extension, 18(5):525-540.

McDonald, R., Heanue, K., Pierce, K., and Horan, B. (2016). Factors influencing new entrant dairy farmer's decision-making process around technology adoption. The Journal of Agricultural Education and Extension, 22(2:163-177.

Mosher, A.T. (1987). An introduction to Agricultural extension. p. 97-127. In J.B. Valera, V. A. Martinez, R.P. Plopino (eds.). An Introduction to Extension Delivery Systems. Island Publishing House, Manila.

Ngoc Chi, T.T., and Yamada, R. (2002). Factors affecting farmers' adoption of technologies in the farming system: a case study in Omon District, Can Tho Province, Mekong Delta. Omorice, 10:94-100.

Reddy G.R., and Reddy, S.J. (2002). Extent of adoption of paddy technologies by the different selected enterprise farmers. Journal of Research ANGRAU, 30:74-88. 
Salehin M.M., Kabir, M.S., Morshed, K.M., and Farid, K.S. (2009). Socio-economic changes of farmers due to adoption of rice production technologies in selected areas of Sherpur district. Journal of Bangladesh Agricultural University, 7:335-341.

Sarma H., Talukder, R.K., and Mishra, P. (2011). Impact of training on adoption of integrated rice-fish farming practices. Indian Journal of Extension Education, 11:87-90.

Sewell, A.M., Hartnett, M.K., Gray, D.I., Blair, H.T., Kemp, P.D., Kenyon, P.R. Morris, S.T., and Wood, B.A. (2017). Using educational theory and research to refine agricultural extension: affordances and barriers for farmers' learning and practice change. The Journal of Agricultural Education and Extension, 23(4): 313-333.

Shanthy, R.T., and Thiagarajan, R. (2011). Interactive multimedia instruction versus traditional training programmes: analysis of their effectiveness and perception. Journal of Agricultural Education and Extension, 17: 459-472.

Suvedi, M., Ghimire, R., and Kaploughitz, M. (2017). Farmers' participation in extension programs and technology adoption in rural Nepal: a logistic regression analysis. The Journal of Agricultural Education and Extension, 23(4): 351-371.

Tsado, J.H., Ojo, M.A., and Ajayi, O.J. (2014). Impact of training the trainers' programme on rice farmers' income and welfare in North Central, Nigeria. Journal of Advanced Agricultural Technologies, 1(2):157-160.

Valera J.B., and Plopino, R.F. (1987). Philosophy and Principles of Extension. p. 51-61. In J.B. Valera, V.A. Martinez and R. P. Plopino. An Introduction to Extension Delivery Systems. Island Publishing House, Manila.

Zeng, J., Lu, X., Tang, X., and Tang, Y. (2004). The system of rice intensification (SRI) for super-high yields or rice in Sichuan Basin, Fourth International Crop Science Congress, Brisbane, Australia. Retrieved September 2017 from http:// www.ciifad.cornell.edu/sri/countries. 